\title{
Synergistically Interacting Dopamine D1 and NMDA Receptors Mediate Nonvesicular Transporter-Dependent GABA Release from Rat Striatal Medium Spiny Neurons
}

\author{
Anton N. M. Schoffelmeer, Louk J. M. J. Vanderschuren, Taco J. De Vries, Francois Hogenboom, \\ George Wardeh, and Arie H. Mulder \\ Research Institute Neurosciences Vrije Universiteit, Department of Pharmacology, Free University, Medical Faculty, \\ 1081 BT Amsterdam, The Netherlands
}

Given the complex interactions between dopamine D1 and glutamate NMDA receptors in the striatum, we investigated the role of these receptors in transporter-mediated GABA release from cultured medium spiny neurons of rat striatum. Like NMDA receptor-mediated $\left[{ }^{3} \mathrm{H}\right]-\mathrm{GABA}$ release, that induced by prolonged (20 min) dopamine D1 receptor activation was enhanced on omission of external calcium, was action potentialindependent (tetrodotoxin-insensitive), and was diminished by the GABA transporter blocker nipecotic acid, indicating the involvement of transporter-mediated release. Interestingly, lowering the external sodium concentration only reduced the stimulatory effect of NMDA. Blockade of $\mathrm{Na}^{+} / \mathrm{K}^{+}$-ATPase by ouabain enhanced NMDA-induced but abolished dopamineinduced release. Moreover, dopamine appeared to potentiate the effect of NMDA on $\left[{ }^{3} \mathrm{H}\right]-$ GABA release. These effects of dopamine were mimicked by forskolin. $\mu$-Opioid receptormediated inhibition of adenylyl cyclase by morphine reduced

In the striatum, dopamine D1 and NMDA receptors display complex interactions regulating the activity of efferent striatal neurons (Cepeda and Levine, 1998). Mesencephalic dopamine and limbic glutamate projections play a critical role in multiple brain functions, including psychomotor activity and rewardrelated incentive learning (Robbins and Everitt, 1996; Pierce and Kalivas, 1997; Kelley, 1999). Changes in the functioning of these neuronal systems have been implicated in various neurological and psychiatric disorders, such as Parkinsonism, schizophrenia, and drug abuse (Albin et al., 1989; Knable and Weinberger, 1997; Koob and Le Moal, 1997). Therefore, it is of interest to elucidate the mechanisms by which dopamine and glutamate, acting on their respective receptors, produce their biological effects on target neurons.

In the striatum, the major targets of released dopamine and glutamate are the GABAergic medium spiny neurons, which represent the predominant type of efferent and recurrent neurons in this brain region (Smith and Bolam, 1990; Di Chiara et al., 1994). It is intriguing that in neurons that display fast action potential-induced exocytotic GABA release, prolonged NMDA receptor activation may cause a delayed and nonvesicular release

\footnotetext{
Received Dec. 16, 1999; revised Feb. 10, 2000; accepted Feb. 22, 2000.

Correspondence should be addressed to Dr. Anton N. M. Schoffelmeer, Research Institute Neurosciences Vrije Universiteit, Department of Pharmacology, Free University, Medical Faculty, Van der Boechorststraat 7, 1081 BT Amsterdam, The Netherlands. E-mail: ANM.Schoffelmeer.Pharm@med.vu.nl.

Copyright (C) 2000 Society for Neuroscience $0270-6474 / 00 / 203496-08 \$ 15.00 / 0$
}

dopamine- and NMDA-induced release. These results confirm previous studies indicating that NMDA receptor activation causes a slow action potential-independent efflux of GABA by reversal of the sodium-dependent GABA transporter on sodium entry through the NMDA receptor channel. Moreover, our data indicate that activation of G-protein-coupled dopamine D1 receptors also induces a transporter-mediated increase in spontaneous GABA release, but through a different mechanism of action, i.e., through cAMP-dependent inhibition of $\mathrm{Na}^{+} / \mathrm{K}^{+}$ATPase, inducing accumulation of intracellular sodium, reversal of the GABA carrier, and potentiation of NMDA-induced release. These receptor interactions may play a crucial role in the behavioral activating effects of psychostimulant drugs.

Key words: dopamine D1 receptors; NMDA receptors; $\mu$-opioid receptors; $\mathrm{Na}^{+} / \mathrm{K}^{+}$-ATPase; GABA transporter; GABA release; striatum

of GABA (for review, see Attwell et al., 1993). There is strong evidence that this delayed release of GABA from the cytoplasmic pool in neurons is caused by entry of sodium ions through the NMDA receptor channel, resulting in accumulation of sodium at the GABA transporter and reversal of the direction of sodiumdependent GABA transport (Erecínska, 1987; Weiss, 1988; Bernath and Zigmond, 1990; Dunlop et al., 1991; Belhage et al., 1993; Duarte et al., 1993; Breukel et al., 1998). The physiological significance of neurotransmitter-induced nonvesicular GABA release is indicated by the fact that amphetamine, which strongly enhances striatal glutamate and dopamine levels, may cause carrier-mediated GABA release from glial cells and/or neurons in the striatum of freely moving rats (Del Arco et al., 1998).

In striatal medium spiny neurons, activation of dopamine D1 receptors enhances the activity of cAMP-dependent protein kinase (PKA), mediating phosphorylation of numerous proteins, including NMDA receptors (Snyder et al., 1998), sodium channels (Schiffmann et al., 1995), and $\mathrm{Na}^{+} / \mathrm{K}^{+}$-ATPase (Bertorello et al., 1990; Fienberg et al., 1998). Moreover, the striatal GABA transporter protein is inhibited by PKA activation (Tian et al., 1994). Therefore, we investigated (1) whether activation of G-protein-coupled dopamine D1 receptors, like activation of NMDA receptors, may cause transporter-mediated increase in spontaneous GABA release from rat striatal medium spiny neurons, (2) the mechanisms underlying receptor-regulated GABA release, and (3) the interactions between dopamine D1, NMDA, and $\mu$-opioid receptors in this action potential-independent re- 
lease. In view of the highly complex interactions between dopamine D1 and NMDA receptors in the striatum and because both neurons and glial cells determine extracellular GABA levels, we primarily studied these issues in neuronal cultures of rat striatum, which consisted of $\sim 95 \%$ of GABA neurons (Bockaert et al., 1986; Weiss, 1988; Van Vliet et al., 1991; Schoffelmeer et al., 1997).

\section{MATERIALS AND METHODS}

Superfusion of brain slices. All experiments were approved by the Animal Care Committee of the Free University of Amsterdam. Male Wistar rats (160-200 gm body weight; Harlan, Zeist, The Netherlands) were decapitated, and nucleus accumbens or caudate putamen slices $(0.3 \times 0.3 \times 1$ $\mathrm{mm}$ ) were prepared using a McIlwain tissue chopper, then incubated with radiolabeled GABA, and superfused essentially as described previously (Schoffelmeer et al., 1988). In short, slices were washed twice with $5 \mathrm{ml}$ Krebs-Ringer's bicarbonate medium containing (in $\mathrm{mM}$ ): 121 $\mathrm{NaCl}, 1.87 \mathrm{KCl}, 1.17 \mathrm{KHPO}_{4}, 25 \mathrm{NaHCO}_{3}, 10 \mathrm{D}-(+)$-glucose, $\mathrm{pH} 7.4$, and (except in experiments in Fig. 1) $1.2 \mathrm{CaCl}_{2}$ and subsequently incubated for $15 \mathrm{~min}$ in this medium, containing $0.1 \mu \mathrm{M}\left[{ }^{3} \mathrm{H}\right]$-GABA under an atmosphere of $95 \% \mathrm{O}_{2}-5 \% \mathrm{CO}_{2}$ at $37^{\circ} \mathrm{C}$. After labeling, the slices were washed and transferred to each of 24 chambers of a superfusion apparatus ( $\sim 3 \mathrm{mg}$ tissue per chamber; $0.2 \mathrm{ml}$ volume) and superfused $(0.25 \mathrm{ml} / \mathrm{min})$ with medium gassed with $95 \% \mathrm{O}_{2}-5 \% \mathrm{CO}_{2}$ at $37^{\circ}$. The GABA transaminase inhibitor amino-oxyacetic acid $(10 \mu \mathrm{M})$ was present throughout the experiments to inhibit $\left[{ }^{3} \mathrm{H}\right]-\mathrm{GABA}$ degradation. The superfusate was collected as 10 min samples after $40 \mathrm{~min}$ of superfusion $(t=40 \mathrm{~min})$. Neurotransmitter release was induced during superfusion by exposing the slices to medium containing dopamine or NMDA for $20 \mathrm{~min}$ at $t=50 \mathrm{~min}$. In each experiment, quadruplicate observations were made.

Primary cultures of striatal neurons. To investigate the regulation of GABA release by dopamine D1, $\mu$-opioid, and NMDA receptors in striatal neurons, primary neuronal cultures were prepared as described previously (Van Vliet et al., 1991; Schoffelmeer et al., 1997). Briefly, the striatum (caudate/putamen + nucleus accumbens) was dissected from 17-d-old rat embryos and dissociated mechanically using a fine-narrowed Pasteur pipette in serum-free medium. Cells were plated in 12-well Linbro culture dishes $\left(6 \times 10^{5}\right.$ cells per milliliter per well $)$ that were coated with poly-L-ornithine $(1.5 \mu \mathrm{g} / \mathrm{ml})$ and medium containing $10 \%$ supplemented calf serum. The culture medium was composed of a 1:1 mixture of DMEM and F-14 nutrient mixture and contained glucose $(0.6 \%)$, glutamine $(2 \mathrm{nM})$, sodium bicarbonate $(3 \mathrm{mM})$, HEPES $(5 \mathrm{~mm})$, streptomycin $(100 \mu \mathrm{g} / \mathrm{ml})$, and penicillin $(100 \mathrm{IU} / \mathrm{ml})$. A defined hormone and salt mixture was added that consisted of insulin $(25 \mu \mathrm{g} / \mathrm{ml})$, transferrin $(100 \mu \mathrm{g} / \mathrm{ml})$, putrescine $(60 \mu \mathrm{M}), \beta$-estradiol $(1 \mathrm{pM})$, and selenium sodium salt (30 nM). Under these culture conditions, the neurons develop an extensive matrix of dendrites and synapses during the first week in culture and are all positive after immunocytochemical staining with antibodies against GABA or GAD. Moreover, because the neurons grow in a serum-free hormone-supplemented medium, only few glial cells $(<5 \%)$ are observed [for further details, see Bockaert et al. (1986) and Van Vliet et al. (1991)]. After $8 \mathrm{~d}$ in vitro, the neurons were washed with $2 \mathrm{ml}$ PBS containing (in $\mathrm{mM}$ ): $137 \mathrm{NaCl}, 2.7 \mathrm{KCl}, 1.2 \mathrm{CaCl}_{2}$, $0.5 \mathrm{MgCl}_{2}, 8 \mathrm{Na}_{2} \mathrm{HPO}_{4}, 1.5 \mathrm{KH}_{2} \mathrm{PO}_{4}, 5$ glucose, $\mathrm{pH} 7.3$, at $37^{\circ} \mathrm{C}$, and subsequently exposed to $2 \mathrm{ml}$ PBS containing $0.1 \mu \mathrm{M}\left[{ }^{3} \mathrm{H}\right]$-GABA. Each dish was washed extensively after $30 \mathrm{~min}$ by changing the $2 \mathrm{ml}$ PBS every $4 \mathrm{~min}$. Seven changes of medium (time needed to reach a steady state of tritium outflow) were followed by stimulation of the neurons in the absence or presence of drugs for $20 \mathrm{~min}$. Amino-oxyacetic acid $(10 \mu \mathrm{M})$ was present throughout the experiments. Quadruplicate observations were made in each experiment.

Calculation of release data. To determine neurotransmitter release from superfused striatal slices, the radioactivity remaining at the end of the superfusion experiment was extracted from the tissue with $0.1 \mathrm{~N} \mathrm{HCl}$. The radioactivity in superfusion fractions and tissue extracts was determined by liquid scintillation counting. The efflux of radioactivity during each collection period was expressed as a percentage of the amount of radioactivity in the slices at the beginning of the respective collection period. The NMDA- and dopamine-induced release of neurotransmitter was calculated by subtracting the spontaneous efflux of radioactivity from the total overflow of radioactivity during stimulation and the following 20 min. Because the release of the neurotransmitters was returned to basal levels during the next $10 \mathrm{~min}$ period, a linear decline from the $10 \mathrm{~min}$ interval before to that $40-50 \mathrm{~min}$ after the onset of stimulation was assumed for calculation of the spontaneous efflux of radioactivity. The spontaneous efflux of radioactivity from nucleus accumbens and caudate putamen slices amounted to $3.4 \pm 0.2$ and $3.2 \pm 0.1 \%$ of total tissue radioactivity, respectively. The evoked release was expressed as percentage of the content of radioactivity of the slices at the start of the stimulation period.

To determine $\left[{ }^{3} \mathrm{H}\right]$-GABA release from cultured striatal neurons, the $2 \mathrm{ml}$ of medium was collected after the $20 \mathrm{~min}$ stimulation period, and $\left[{ }^{3} \mathrm{H}\right]$ remaining in the cells was extracted with $1 \mathrm{ml} 0.1 \mathrm{~N} \mathrm{HCl}$. Radioactivity in the media and tissue extracts was determined by liquid scintillation counting. $\left[{ }^{3} \mathrm{H}\right]$-GABA release from the neurons was expressed as the radioactivity found in the stimulation media as percentage of total radioactivity present in the media and tissue extracts. Evoked neurotransmitter release during the 20 min stimulation period was determined by subtracting release in the absence of stimulatory agents from that found in their presence. The spontaneous efflux of radioactivity from the neurons during the stimulation period amounted to $3.5 \pm 0.2 \%$ of total radioactivity.

The effects of drugs were analyzed using one-way ANOVAs, followed by Student-Newman-Keuls tests where appropriate.

Materials. $\left[{ }^{3} \mathrm{H}\right]$-GABA $(57 \mathrm{Ci} / \mathrm{mmol})$ was purchased from the Radiochemical Center (Amersham, UK). NMDA, dopamine, naloxone, forskolin, 1,9-dideoxyforskolin, tetrodotoxin (TTX), ouabain, nipecotic acid, poly-L-ornithine, streptomycin, penicillin, insulin, transferrin, putrescine, $\beta$-estradiol, dexamethasone 21-phosphate, and aldosterone 21-acetate were obtained from Sigma (St. Louis, MO); DMEM and F-12 nutrient mixture and fetal calf serum were from Life Technologies (Paisley, UK); and HEPES, glucose, glutamine, sodium carbonate, and selenium sodium salt were from Merck (Darmstadt, FRG). Morphine hydrochloride was obtained from O.P.G. (Utrecht, The Netherlands). SCH23390 and $\mathrm{R}(-)-2$ amino-5-phosphonovaleric acid (AP-5) was from RBI (Natick, MA).

\section{RESULTS \\ Interacting dopamine D1 and NMDA receptors differentially enhance transporter-mediated GABA release from striatal neurons}

Preliminary experiments revealed that exposure of superfused rat striatal slices to dopamine or NMDA caused a delayed increase in $\left[{ }^{3} \mathrm{H}\right] \mathrm{GABA}$ efflux (as opposed to rapid action potentialdependent release), reaching a maximum 10-20 min after drug exposure [for discussion, see Belhage et al. (1993)]. Exposure of nucleus accumbens or caudate putamen slices for $20 \mathrm{~min}$ to a (submaximally effective) concentration of dopamine or NMDA $(30 \mu \mathrm{M})$ only slightly enhanced the efflux of $\left[{ }^{3} \mathrm{H}\right]-\mathrm{GABA}$ when 1.2 mM calcium was present in the medium. As shown in Figure 1, lowering the external calcium concentration caused a profound increase in the stimulatory effects of dopamine and NMDA, indicating the occurrence of nonexocytotic neurotransmitter release. To investigate this phenomenon at the level of GABA neurons in more detail, we investigated whether this delayed calcium-independent release of GABA after dopamine or NMDA exposure is also apparent in primary cultures of striatal medium spiny neurons at $8 \mathrm{~d}$ in vitro (i.e., after maturation of GABA neurons). Indeed, the inverse relationship between the external calcium concentration and dopamine- or NMDAinduced $\left[{ }^{3} \mathrm{H}\right]$-GABA efflux was also found to occur in cultured GABA neurons (Fig. 1). In these cultured neurons, dopamineand NMDA-induced release (in excess of basal efflux) could be reliably measured on $20 \mathrm{~min}$ exposure to dopamine or NMDA even in the presence of $1.2 \mathrm{~mm}$ calcium, amounting to $\sim 3$ and $7 \%$ of total radioactivity, respectively. Therefore, subsequent experiments were performed in the presence of calcium, allowing us to study the GABA release mechanism under (quasi) physiological conditions. Figure 2 shows that dopamine and NMDA enhanced $\left[{ }^{3} \mathrm{H}\right]-\mathrm{GABA}$ release in striatal cultures in a concentration- 
Figure 1. Role of external calcium on NMDA- and dopamine-evoked release of $\left[{ }^{3} \mathrm{H}\right]$-GABA from superfused slices of rat nucleus accumbens and caudate putamen and from cultured striatal GABA neurons. Brain slices and cultured neurons were exposed to NMDA or dopamine $(D A)$ for $20 \mathrm{~min}$. Neurotransmitter release was calculated as percentage of total radioactivity in excess of spontaneous efflux. Data represent means \pm SEM of 12 observations. Quadruplicate observations were made per experiment. * $p<0.001$ as compared with values in the absence of calcium (Student-Newman-Keuls).

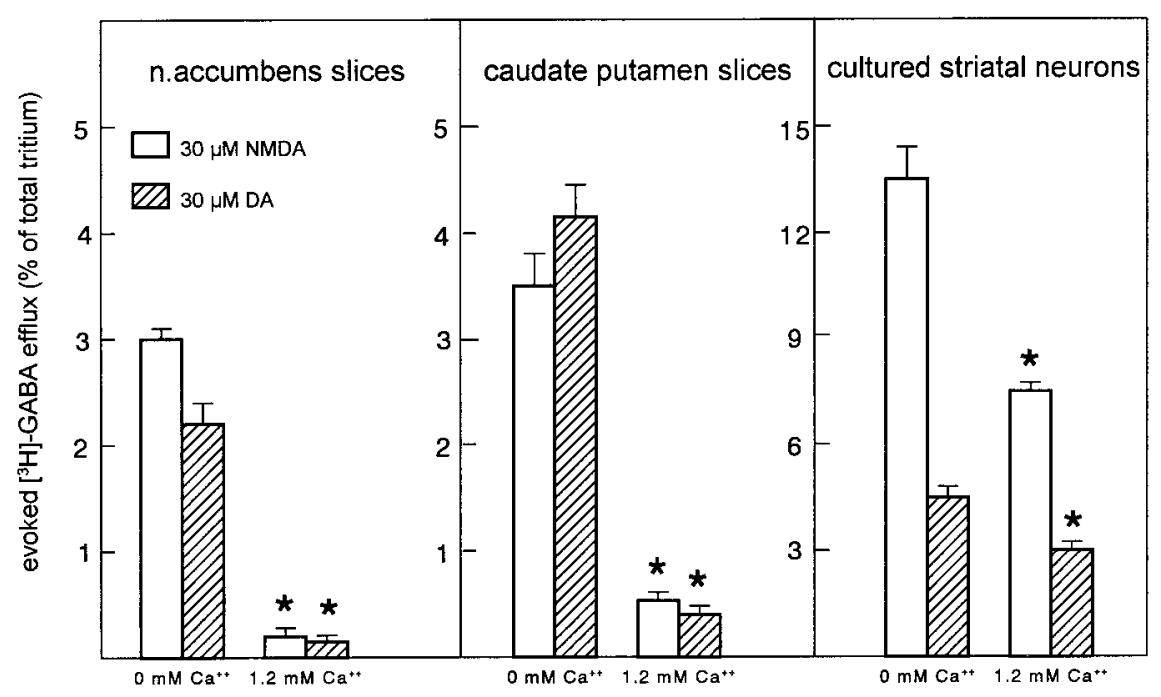

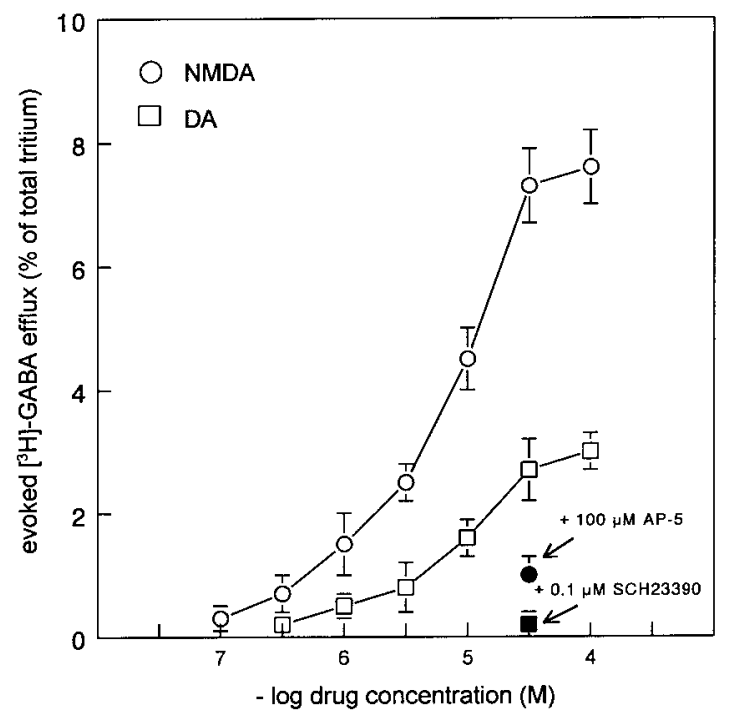

Figure 2. Dose-dependent stimulation of $\left[{ }^{3} \mathrm{H}\right]-\mathrm{GABA}$ release from cultured striatal GABA neurons by NMDA and dopamine and its inhibition by receptor selective antagonists. The neurons were exposed to NMDA or dopamine $(D A)$ for $20 \mathrm{~min}$. The NMDA receptor antagonist AP-5 and the dopamine D1 receptor antagonist SCH23390 were present $20 \mathrm{~min}$ before and during exposure to NMDA or dopamine. Neurotransmitter release was calculated as percentage of total radioactivity in excess of spontaneous efflux. The antagonists alone did not change spontaneous efflux of radioactivity. Data represent means \pm SEM of 12 observations. Quadruplicate observations were made per experiment.

dependent manner. Moreover, although $30 \mu \mathrm{M}$ NMDA-evoked release was inhibited by the selective NMDA receptor antagonist AP-5, that induced by $30 \mu \mathrm{M}$ dopamine was reduced by the selective dopamine D1 receptor antagonist SCH23390, indicating the involvement of NMDA and D1 receptors. As might be expected, AP-5 (100 $\mu \mathrm{M})$ and SCH23390 (0.1 $\mu \mathrm{M})$ did not alter $\left[{ }^{3} \mathrm{H}\right]-$ GABA release induced by dopamine and NMDA, respectively.

Exposure of the neurons to $30 \mu \mathrm{M}$ nipecotic acid, a selective blocker of the GABA transporter, caused an almost fourfold increase in spontaneous $\left[{ }^{3} \mathrm{H}\right]-\mathrm{GABA}$ efflux and completely prevented NMDA and dopamine receptor-stimulated $\left[{ }^{3} \mathrm{H}\right]-\mathrm{GABA}$ release, whereas blockade of voltage-gated sodium channels with $1 \mu \mathrm{M}$ TTX was ineffective in this respect (Fig. 3). Therefore,

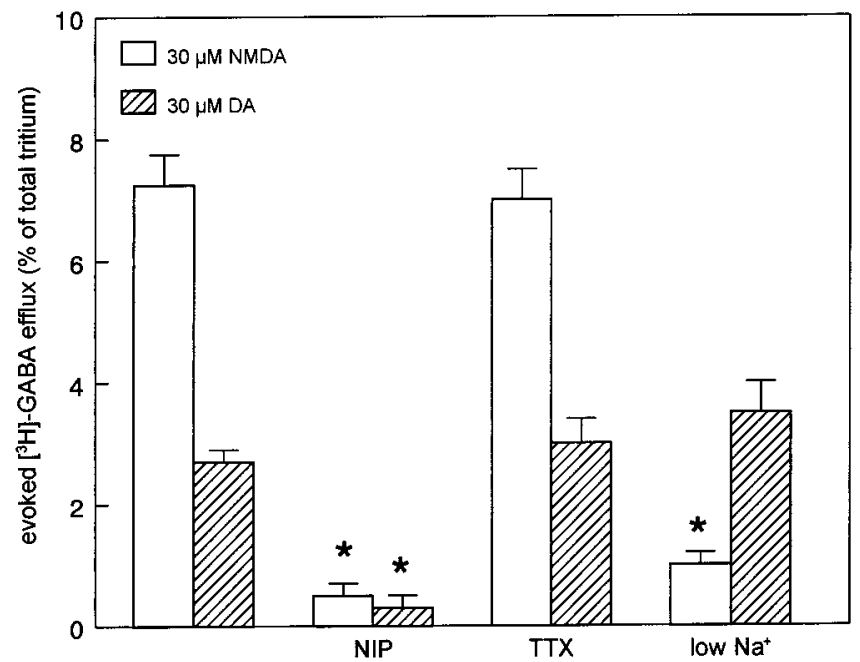

Figure 3. Effect of nipecotic acid, tetrodotoxin, and reduction of the external sodium concentration on NMDA- and dopamine-evoked $\left[{ }^{3} \mathrm{H}\right]-$ GABA release from cultured striatal neurons. The neurons were exposed to NMDA or dopamine $(D A)$ for $20 \mathrm{~min}$. The GABA transporter blocker nipecotic acid $(N I P, 30 \mu \mathrm{M})$, the sodium channel blocker tetrodotoxin $(T T X, 1 \mu \mathrm{M})$, and the medium with sodium chloride replaced by choline chloride were present $20 \mathrm{~min}$ before and during NMDA or dopamine exposure. Neurotransmitter release was calculated as percentage of total radioactivity in excess of spontaneous efflux. TTX alone did alter spontaneous efflux. Nipecotic acid and exposure to low sodium medium enhanced spontaneous $\left[{ }^{3} \mathrm{H}\right]-\mathrm{GABA}$ efflux from $3.3 \pm 0.2$ to $12.4 \pm 0.3$ and $11.6 \pm 0.2 \%$, respectively. Data represent means \pm SEM of $12-16$ observations. Quadruplicate observations were made per experiment. ${ }^{*} p<$ 0.001 as compared with control values (Student-Newman-Keuls).

$\left[{ }^{3} \mathrm{H}\right]-\mathrm{GABA}$ release appears to be transporter-mediated and does not seem to involve calcium-dependent exocytotic release. Replacement of sodium chloride by choline chloride (causing a $\sim 3.5$-fold increase in spontaneous efflux of the neurotransmitter) strongly reduced NMDA-induced release, leaving that induced by dopamine unchanged (Fig. 3). Accordingly, dopamine D1 receptor-mediated release (unlike NMDA receptor-mediated release) does not appear to be caused by an inward transmembrane sodium influx.

Pharmacological inhibition of outward sodium transport by the $\mathrm{Na}^{+} / \mathrm{K}^{+}$-ATPase inhibitor ouabain $(10 \mu \mathrm{M})$ induced a similar increase in $\left[{ }^{3} \mathrm{H}\right]-\mathrm{GABA}$ release as $30 \mu \mathrm{M}$ dopamine. Interestingly, 


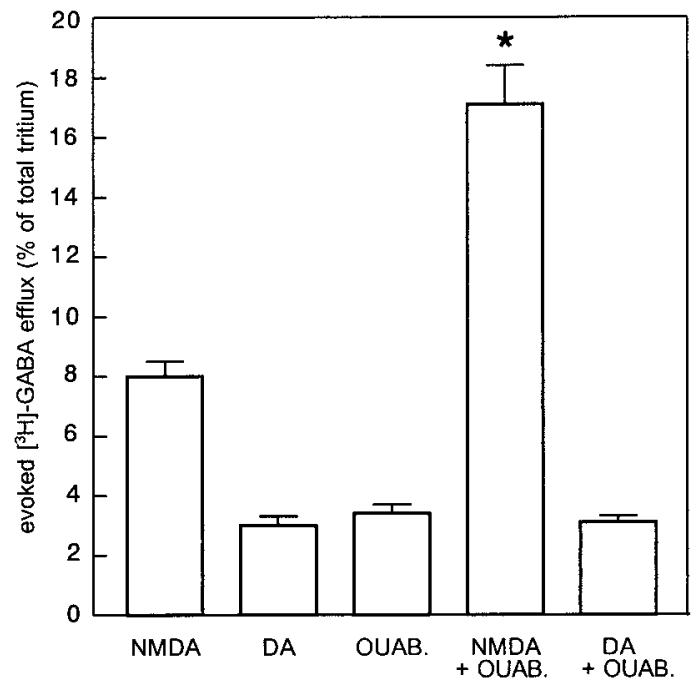

Figure 4. Effect of blockade of $\mathrm{Na}^{+} / \mathrm{K}^{+}$-ATPase on $\left[{ }^{3} \mathrm{H}\right]-\mathrm{GABA}$ release from cultured striatal GABA neurons and its stimulation by NMDA or dopamine. The neurons were exposed to the sodium pump inhibitor ouabain $(O U A B, 10 \mu \mathrm{M})$ and/or NMDA $(30 \mu \mathrm{M})$ or dopamine $(D A, 30$ $\mu \mathrm{M})$ for $20 \mathrm{~min}$. Neurotransmitter release was calculated as percentage of total radioactivity in excess of spontaneous efflux. Data represent means \pm SEM of 12-16 observations. Quadruplicate observations were made per experiment. * $p<0.001$ as compared with values in the presence of ouabain or NMDA alone (Student-Newman-Keuls).

ouabain strongly potentiated NMDA-induced release and diminished that induced by dopamine (Fig. 4). At a higher concentration of ouabain $(100 \mu \mathrm{M})$, causing a $\sim 3.5$-fold increase in $\left[{ }^{3} \mathrm{H}\right]-$ GABA efflux, NMDA-induced neurotransmitter release amounted to no less than $36 \%$ of total tissue content, whereas that induced by dopamine was abolished (data not shown). These data strongly suggest that dopamine-induced release is caused by (partial) inhibition of the sodium pump. As might then be expected, exposure of striatal neurons to dopamine potentiated NMDA-induced $\left[{ }^{3} \mathrm{H}\right]$-GABA release (Fig. 5). Such a synergistic interaction between dopamine D1 and NMDA receptors was also observed when calcium was omitted from the medium.

\section{Dopamine D1 and $\mu$-opioid receptors regulate transporter-mediated GABA release in a cAMP-dependent manner}

Exposure of striatal neurons to the adenylyl cyclase activator forskolin $(10 \mu \mathrm{M})$ mimicked the effect of dopamine D1 receptor activation on $\left[{ }^{3} \mathrm{H}\right]$-GABA release, whereas the inactive enantiomer 1,9-dideoxyforskolin did not affect neurotransmitter efflux (Fig. 6). Like dopamine, forskolin appeared to potentiate NMDA-induced $\left[{ }^{3} \mathrm{H}\right]-G A B A$ release. Moreover, forskolin did not further enhance neurotransmitter release on inhibition of $\mathrm{Na}^{+} / \mathrm{K}^{+}$-ATPase by $10 \mu \mathrm{M}$ ouabain. Figure 6 also shows that dopamine (unlike NMDA) no longer enhanced neurotransmitter release when the neurons were simultaneously exposed to forskolin. Activation of $\mu$-opioid receptors, inhibitorily coupled to adenylyl cyclase in these neurons (Van Vliet et al., 1991), by 10 $\mu \mathrm{M}$ morphine caused a naloxone-reversible inhibition of NMDAand dopamine-induced $\left[{ }^{3} \mathrm{H}\right]$-GABA release (Figs. 7, 8). These inhibitory effects were blocked by forskolin, indicating the involvement of a cAMP-dependent mechanism.

\section{DISCUSSION}

The release of biogenic amines, such as dopamine and noradrenaline, in the brain on activation of NMDA receptors is action

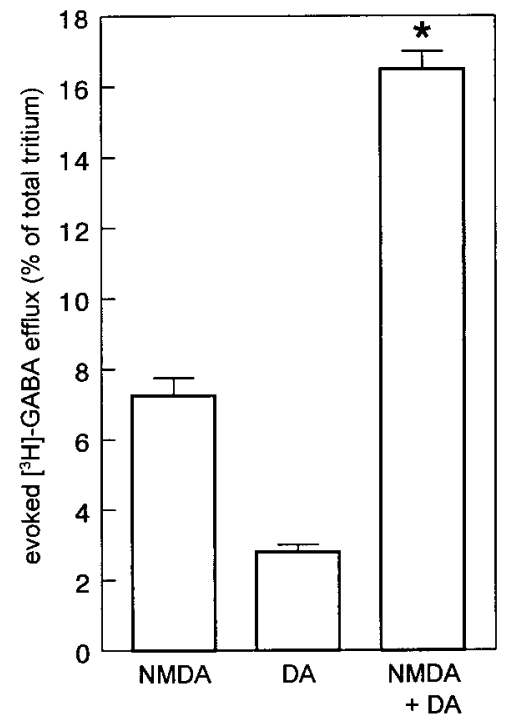

Figure 5. Synergistic stimulatory effect of NMDA and dopamine on $\left[{ }^{3} \mathrm{H}\right]$-GABA release from cultured striatal GABA neurons. The neurons were exposed to NMDA $(30 \mu \mathrm{M})$ and/or dopamine $(D A, 30 \mu \mathrm{M})$ for 20 min. Neurotransmitter release was calculated as percentage of total radioactivity in excess of spontaneous efflux. Data represent means \pm SEM of 24 observations obtained in six separate experiments. ${ }^{*} p<0.01$ as compared with the sum of NMDA- and dopamine-evoked release (Student-Newman-Keuls).

potential-mediated (tetrodotoxin sensitive) and completely dependent on the presence of extracellular calcium, involving exocytotic release from a vesicular pool (Wang et al., 1992; Malva et al., 1994). However, the neurotransmitter GABA, found in vesicles as well as in the cytosol of GABAergic forebrain neurons (Maycox et al., 1990), is released not only by exocytosis on arrival of an action potential but also in an action potential-independent nonvesicular fashion, which may even predominate after prolonged activation of NMDA receptors. Studies on the nature of this NMDA-induced mechanism in olfactory (Jaffe and Vaello, 1988), striatal (Weiss, 1988), cortical (Belhage et al., 1993), and hippocampal (Breukel et al., 1998) neurons as well as in chick retina cells (Duarte et al., 1993) have shown that this is caused by reversal of GABA transporter, driven by the electrochemical sodium gradient, on sodium entry through the NMDA receptor channel (for review, see Attwell et al., 1993). Moreover, the activity of the GABA transporter appeared to be reduced by external calcium (Bernath and Zigmond, 1990; Duarte et al., 1993). The inverse relationship between the activity of the GABA transporter and external calcium is most likely attributable to the activity of the $\mathrm{Na}^{+} / \mathrm{Ca}^{2+}$-exchanger, promoting calcium efflux in exchange for sodium (Blaustein et al., 1991; Duarte et al., 1993). This nonexocytotic increase in spontaneous GABA efflux may represent a continuous release mechanism that occurs far from the active zones (e.g., at the level of neuronal cell bodies) (Belhage et al., 1993; Duarte et al., 1993). Because NMDA receptormediated nonexocytotic GABA efflux may actually be a major effect of glutamate on central GABA neurons even in the presence of calcium and was recently shown to occur in rat striatum in vivo (Del Arco et al., 1998), it seems to represent a physiological phenomenon rather than the result of artificial stimulatory conditions (Sihra and Nichols, 1987). However, it was unknown until now whether this action potential-independent release mechanism is also regulated by neurotransmitters other than 
Figure 6. Effect of activation of adenylyl cyclase by forskolin on $\left[{ }^{3} \mathrm{H}\right]-$-GABA release from cultured striatal GABA neurons and its stimulation by NMDA, dopamine, and ouabain. The neurons were exposed to NMDA $(30 \mu \mathrm{M})$, dopamine $(30 \mu \mathrm{M})$, ouabain $(10 \mu \mathrm{M})$, and/or forskolin (FORSK, $10 \mu \mathrm{M})$ or 1,9-dideoxyforskolin (1,9-DD-FORSK, $10 \mu \mathrm{M})$ for $20 \mathrm{~min}$. Neurotransmitter release was calculated as percentage of total radioactivity in excess of spontaneous efflux. Data represent means of $12-16$ observations. Quadruplicate observations were made per experiment. ${ }^{*} p<0.01$ as compared with the sum of NMDA- and forskolin-evoked release (Student-Newman-Keuls).

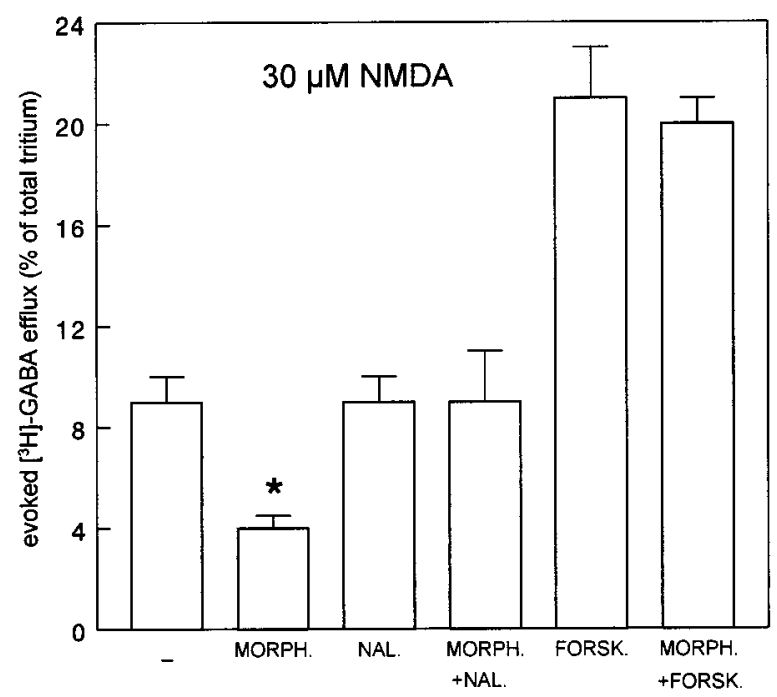

Figure 7. $\mu$-Opioid receptor-mediated inhibition of NMDA-evoked $\left[{ }^{3} \mathrm{H}\right]-$ GABA release from cultured striatal GABA neurons and its reversal by forskolin. The neurons were exposed to NMDA or NMDA + forskolin $(F O R S K, 10 \mu \mathrm{M})$ for $20 \mathrm{~min}$. The $\mu$-opioid receptor agonist morphine $(M O R P H, 10 \mu \mathrm{M})$ or the antagonist naloxone $(N A L, 1 \mu \mathrm{M})$ or both were present $20 \mathrm{~min}$ before and during stimulation. Neurotransmitter release was calculated as percentage of total radioactivity in excess of spontaneous efflux. Data represent means \pm SEM of 12 observations. Quadruplicate observations were made per experiment. ${ }^{*} p<0.01$ as compared with control values (Student-Newman-Keuls).

glutamate, such as those activating stimulatory and inhibitory G-protein-coupled receptors.

In agreement with the involvement of nonexocytotic GABA release, our present study shows that $\left[{ }^{3} \mathrm{H}\right]-$ GABA efflux in cultured striatal neurons (as in striatal slices) on prolonged NMDA receptor activation is inversely related to the external calcium concentration. Moreover, NMDA-induced release was strongly reduced on lowering the external sodium concentration (i.e., dependent on the electrochemical sodium gradient), unchanged by blockade of voltage-gated sodium channels with tetrodotoxin (i.e., independent of action potentials), and virtually abolished by the selective GABA transporter nipecotic acid as shown by others
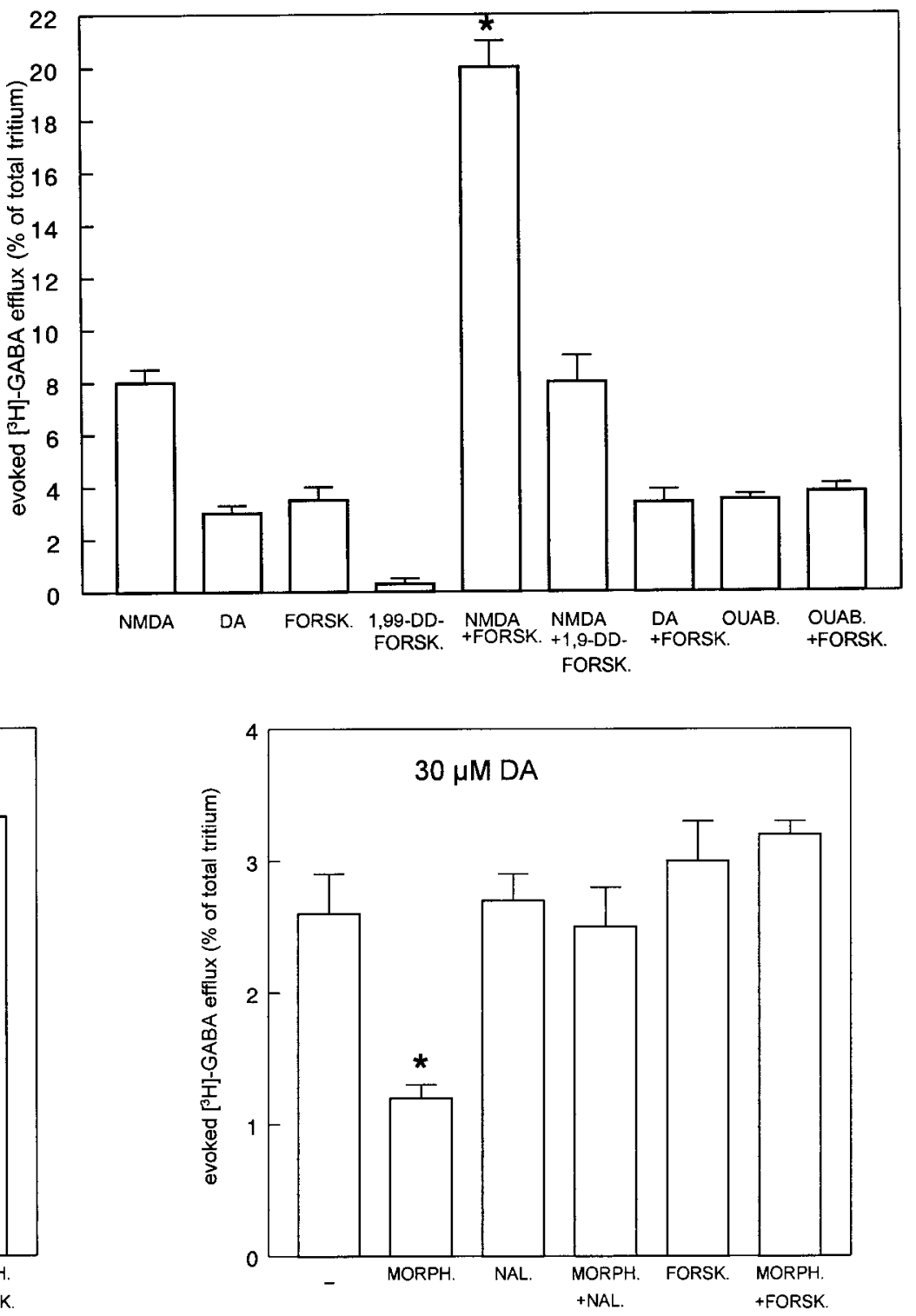

Figure 8. $\mu$-Opioid receptor-mediated inhibition of dopamine-evoked $\left[{ }^{3} \mathrm{H}\right]$-GABA release from cultured striatal GABA neurons and its reversal by forskolin. The neurons were exposed to dopamine $(D A)$ or dopamine + forskolin $(F O R S K, 10 \mu \mathrm{M})$ for $20 \mathrm{~min}$. The $\mu$-opioid receptor agonist morphine $(M O R P H, 10 \mu \mathrm{M})$ or the antagonist naloxone $(N A L, 1 \mu \mathrm{M})$ or both were present $20 \mathrm{~min}$ before and during stimulation. Neurotransmitter release was calculated as percentage of total radioactivity in excess of spontaneous efflux. Data represent means \pm SEM of 12 observations. Quadruplicate observations were made per experiment. ${ }^{*} p<0.01$ as compared with control values (Student-Newman-Keuls).

(see above). Accordingly, blockade of outward sodium transport after inhibition of $\mathrm{Na}^{+} / \mathrm{K}^{+}$-ATPase by ouabain strongly enhanced NMDA-induced GABA efflux.

Although dopamine D1 receptors in striatal medium spiny neurons are well known to be inhibitorily linked to voltage-gated sodium and calcium channels (Surmeier et al., 1992, 1995; Cepeda and Levine, 1998; Schiffmann et al., 1995; Zhang et al., 1998), dopamine D1 receptor activation appeared to enhance rather than reduce $\left[{ }^{3} \mathrm{H}\right]-\mathrm{GABA}$ efflux from cultured striatal neurons (as observed in slices of rat striatum). Like NMDA-induced $\left[{ }^{3} \mathrm{H}\right]-\mathrm{GABA}$ efflux, that evoked by dopamine appeared to be reduced by external calcium and to be diminished on blockade of 


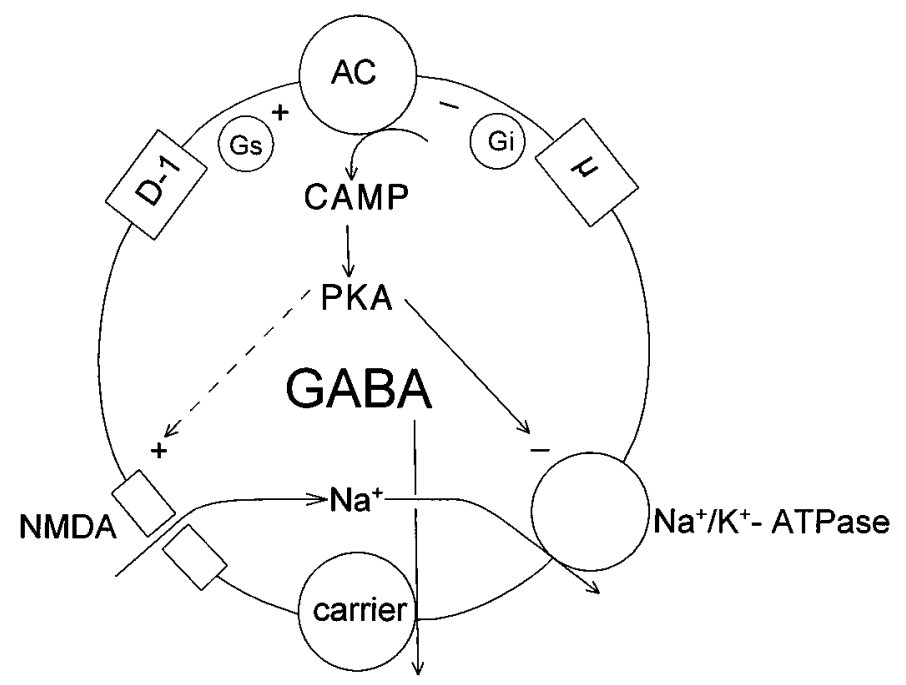

Figure 9. Proposed mechanisms underlying NMDA-, dopamine D1-, and $\mu$-opioid receptor-mediated modulation of calcium-independent GABA release from rat striatal neurons. In this model, activation of NMDA receptors causes sodium entry through the receptor channel leading to a reduction of the electrochemical transmembrane sodium gradient, which in turn results in reversal of the GABA transporter mediating GABA release from the cytoplasmic pool. Activation of dopamine D1 receptors increases adenylyl cyclase activity, leading to cAMP/ protein kinase A-dependent phosphorylation of $\mathrm{Na}^{+} / \mathrm{K}^{+}$-ATPase. The resulting inhibition of sodium pump activity is assumed to cause a slow accumulation of intracellular sodium leading to (1) reversal of the GABA transporter causing nonvesicular GABA release and (2) potentiation of the effect of NMDA receptor activation on the intracellular sodium concentration. Activation of $\mu$-opioid receptors causes inhibition of dopamine-stimulated adenylyl cyclase activity, thereby inhibiting this effect of dopamine D1 receptor activation. A cAMP/protein kinase A-dependent regulation of the phosphorylation of NMDA receptors, proposed by others (Blank et al., 1997; Snyder et al., 1998), is also included in this model because it may also play a role in the synergistic effect of dopamine and NMDA on transporter-mediated GABA release in addition to inhibition of sodium pump activity.

the GABA transporter with nipecotic acid. Therefore, dopamineinduced release also seems to be caused by reversal of the GABA transporter. Nevertheless, dopamine D1 receptor-mediated $\left[{ }^{3} \mathrm{H}\right]$ GABA efflux differed from that induced by NMDA receptor activation in that (1) it was unaffected by lowering the external sodium concentration and (2) completely blocked by ouabain. The finding that lowering the external sodium concentration did not reduce the effect of dopamine is not surprising because dopamine D1 receptor activation in striatal medium spiny neurons is not associated with an increase of transmembrane sodium entry. On the other hand, the finding that ouabain completely prevented the stimulatory effect of dopamine on $\left[{ }^{3} \mathrm{H}\right]-\mathrm{GABA}$ efflux, whereas it strongly enhanced the effect of NMDA, indicates that dopamine D1 receptor activation may cause $\left[{ }^{3} \mathrm{H}\right]$ GABA release through (partial) inhibition of $\mathrm{Na}^{+} / \mathrm{K}^{+}$-ATPase. Accordingly, activation of dopamine D1 receptors may be expected to lead to a slow accumulation of intracellular sodium ions, thereby reducing the transmembrane electrochemical gradient of sodium. Indeed, it has been well established that dopamine D1 receptor activation in isolated striatal medium spiny neurons causes inhibition of ouabain-sensitive $\mathrm{Na}^{+} / \mathrm{K}^{+}$-ATPase in a cAMP/PKA-dependent manner (Bertorello et al., 1990; Fienberg et al., 1998). In agreement with such a mechanism of action, dopamine D1 receptor activation potentiated sodium-dependent NMDA-induced $\left[{ }^{3} \mathrm{H}\right]$-GABA efflux. The cAMP/PKA-dependence of these effects of dopamine is indicated by the fact that activation of adenylyl cyclase by forskolin mimicked the effect of dopamine on $\left[{ }^{3} \mathrm{H}\right]$-GABA efflux, potentiated the stimulatory effect of NMDA, and prevented a further increase of neurotransmitter release by dopamine. Moreover, just like the stimulatory effect of dopamine, that of forskolin was abolished when $\mathrm{Na}^{+} / \mathrm{K}^{+}$ATPase was inhibited. In addition, activation of $\mu$-opioid receptors, previously shown to be inhibitorily coupled to adenylyl cyclase in striatal slices and cultured medium spiny neurons (Schoffelmeer et al., 1988; Van Vliet et al., 1991), inhibited NMDA- and dopamine-stimulated $\left[{ }^{3} \mathrm{H}\right]-\mathrm{GABA}$ efflux, and this inhibitory effect was prevented by forskolin.

Because forskolin (unlike the inactive enantiomer 1,9dideoxyforskolin) blocked the effect of dopamine on carriermediated neurotransmitter efflux, the involvement of phospholipase C-coupled dopamine D1 receptors (Chergui and Lacey, 1999) is unlikely. Accordingly, it was demonstrated recently that dopamine D1 receptor-mediated inhibition of $\mathrm{Na}^{+} / \mathrm{K}^{+}$-ATPase in rat striatal neurons is independent of the stimulatory effect of dopamine on phospholipid-dependent protein kinase (PKC) (Nishi et al., 1999). In addition, the observation that dopamine potentiated rather than inhibited NMDA-induced $\left[{ }^{3} \mathrm{H}\right]-\mathrm{GABA}$ efflux indicates that the effect of $\mathrm{D} 1$ receptor activation does not involve cAMP-dependent phosphorylation of the GABA transporter inhibiting GABA reuptake at the level of striatal nerve terminals (Tian et al., 1994).

Taken together, our present data indicate that dopamine D1 and NMDA receptors differentially mediate an accumulation of intracellular sodium in striatal medium spiny neurons, causing nonvesicular GABA transporter-mediated neurotransmitter release. Moreover, the synergistic interaction between these receptors seems to be the result of sodium influx through the NMDA receptor channel on activation of these receptors and dopamine D1 receptor/cAMP-mediated inhibition of the sodium pump (preventing outward sodium transport). It should be emphasized here that in addition to the inhibitory effect of dopamine D1 receptor activation on $\mathrm{Na}^{+} / \mathrm{K}^{+}$-ATPase in striatal medium spiny neurons, dopamine $\mathrm{D} 1$ receptors are also known to enhance NMDA receptor functioning through cAMP/PKA-dependent regulation of the phosphorylation state of NMDA receptors (Blank et al., 1997; Snyder et al., 1998). Therefore, dopamine D1 receptor-mediated phosphorylation of NMDA receptors, in addition to cAMP-dependent inhibition of the sodium pump, may well play an additional role in the synergistic effect of dopamine on NMDA-evoked GABA efflux and its inhibition by $\mu$-opioid receptor activation (Fig. 9).

Although the present study indicates that G-protein-coupled receptors, like ionotropic receptors, may modulate transmembrane GABA transport in striatal medium spiny neurons in a sodium-dependent manner, additional mechanisms may play a role in the regulation of GABA transporters by striatal neurotransmitters. In this respect, the functioning and internalization of GABA (GAT 1) transporters has been shown to be regulated by second messengers and by proteins of the so-called SNARE complex. However, the initial triggers for this regulation are as yet largely unknown (Beckman et al., 1998; Bernstein and Quick, 1999).

The relative contribution of this slow neurotransmitter receptorregulated nonvesicular release to striatal extracellular GABA levels in vivo can be expected to depend on the extracellular concentrations of dopamine and glutamate as well as on the frequency of action potentials in medium spiny neurons and their 
excitatory input causing exocytotic synaptic release of GABA. Interestingly, because amphetamine-induced transporter-mediated GABA efflux appeared to represent $\sim 40 \%$ of the amount of GABA released in rat striatum in vivo (Del Arco et al., 1998), it may be quite substantial after psychostimulant exposure associated with a sustained increase in extracellular dopamine and glutamate levels (Kuczenski and Segal, 1989; Xue et al., 1996; Reid et al., 1997). Recent studies indicate that dopamine D1 receptors in the striatum display a gating property that by enhancing sustained glutamate-induced activation GABA neurons could play a crucial role in the behavioral activating effects of psychostimulants (Kalivas and Nakamura, 1999). In this respect, the synergistic interaction between dopamine D1 and NMDA receptors shown here may be of particular interest. A sustained increase in extracellular GABA levels reduces the excitability of input and output neurons of the striatum, including that of efferent GABA neurons through lateral inhibition (Groves, 1983). Therefore, nonvesicular transporter-mediated GABA release may contribute to the inhibitory effect of psychostimulants on the firing rate of (subsets of) afferent and efferent striatal neurons as demonstrated in vivo (White et al., 1993; Nicola et al., 1996). By regulating both action potential-dependent exocytotic GABA release and transporter-mediated nonvesicular GABA efflux, dopamine, glutamate, and opioids may orchestrate a pattern of activation and inhibition among striatal neurons that may be a necessary condition for the psychomotor and rewarding effects of drugs.

\section{REFERENCES}

Albin RL, Young AB, Penney JB (1989) The functional anatomy of basal ganglia disorders. Trends Neurosci 12:366-375.

Attwell D, Barbour B, Szatkowski M (1993) Nonvesicular release of neurotransmitter. Neuron 11:401-407.

Beckman ML, Bernstein EM, Quick MW (1998) Protein kinase C regulates the interaction between a GABA transporter and syntaxin 1A. J Neurosci 18:6103-6112.

Belhage B, Hansen GH, Schousboe A (1993) Depolarization by $\mathrm{K}^{+}$and glutamate activates different neurotransmitter release mechanisms in GABAergic neurons: vesicular versus non-vesicular release of GABA. Neuroscience 54:1019-1034.

Bernath S, Zigmond MJ (1990) Calcium-independent GABA release from striatal slices: the role of calcium channels. Neuroscience 36:677-682.

Bernstein EM, Quick MW (1999) Regulation of gamma-aminobutyric acid (GABA) transporter by extracellular GABA. J Biol Chem 274:889-895.

Bertorello A, Hopfield JF, Aperia A, Greengard P (1990) Inhibition by dopamine of $\left(\mathrm{Na}^{+}+\mathrm{K}^{+}\right)$ATPase activity in neostriatal neurons through $\mathrm{D}_{1}$ and $\mathrm{D}_{2}$ dopamine receptor synergism. Nature 347:386-388.

Blank T, Nijholt I, Teichert U, Kugler H, Behrsing H, Fienberg A, Greengard P, Spiess J (1997) The phosphoprotein DARPP-32 mediated cAMP-dependent potentiation of striatal $N$-methyl-D-aspartate responses. Proc Natl Acad Sci USA 94:14859-14864.

Blaustein MP, Goldman WF, Fontana G, Krueger BK, Santiago EM, Steele TD, Weiss DN, Yarowski PJ (1991) Physiological role of the sodium-calcium exchanger in nerve and muscle. Ann NY Acad Sci USA 639:254-274.

Bockaert J, Gabrion F, Sladeczek F, Pin J-P, Recasens M, Sebben M, Kemp D, Dumuis A, Weiss S (1986) A primary culture of striatal neurons: a model of choice for pharmacological and biochemical studies of neurotransmitter receptors. J Physiol (Paris) 81:219-226.

Breukel AIM, Besselsen E, Lopes da Silva FH, Ghijssen WEJM (1998) A presynaptic $N$-methyl-D-aspartate autoreceptor in rat hippocampus modulating amino acid release from a cytoplasmic pool. Eur J Neurosci 10:106-114.

Cepeda C, Levine MS (1998) Dopamine and $N$-methyl-D-aspartate receptor interactions in the neostriatum. Dev Neurosci 20:1-18.

Chergui K, Lacey MG (1999) Modulation by dopamine $\mathrm{D}_{1}$-like receptors of synaptic transmission and NMDA receptors in rat nucleus accumbens is attenuated by the protein kinase C inhibitor Ro 32-0432. Neuropharmacology 38:223-231.

Del Arco A, Castañeda, Mora F (1998) Amphetamine releases GABA in striatum of the freely moving rat: involvement of calcium and high affinity transporter mechanisms. Neuropharmacology 37:199-205.

Di Chiara G, Morelli M, Consolo S (1994) Modulatory functions of neurotransmitters in the striatum: Ach/dopamine/NMDA interactions. Trends Neurosci 17:228-233.

Duarte CB, Ferreira IL, Santos PL, Oliveira CR, Carvalho AP (1993) Glutamate increases the $\left[\mathrm{Ca}^{2+}\right] \mathrm{i}$ but stimulates $\mathrm{Ca}^{2+}$-independent release of $\left[{ }^{3} \mathrm{H}\right]-\mathrm{GABA}$ in cultured chick retina cells. Brain Res 611:130-138.

Dunlop J, Grieve A, Schousboe A, Griffiths R (1991) Stimulation of ã- $\left[{ }^{3} \mathrm{H}\right]$-aminobutyric acid release from cultured mouse cerebral cortex neurons by sulphur-containing excitatory amino acid transmitter candidates: receptor activation mediates two distinct mechanisms of release. J Neurochem 57:1388-1397.

Erecínska M (1987) The neurotransmitter amino acid transporter systems: a fresh outlook on an old problem. Biochem Pharmacol 36:3547-3555.

Fienberg AA, Hiroi N, Mermelstein PG, Song W-J, Snyder GL, Nishi A, Cheramy A, O'Callaghan JP, Miller DB, Cole DG, Corbett R, Haile CN, Cooper DC, Onn SP, Grace AA, Ouimet CC, White FJ, Hyman SE, Surmeier DJ, Girault J-A, Nestler EJ, Greengard P (1998) DARPP-32: regulator of the efficacy of dopaminergic neurotransmission. Science 281:838-842.

Groves PM (1983) A theory of the functional organization of the neostriatum and the neostriatal control of voluntary movement. Brain Res Rev 5:109-132.

Jaffe EH, Vaello ML (1988) Two different release mechanisms of ${ }^{3} \mathrm{H}$ GABA induced by glutamate in the rat olfactory bulb. P R Health Sci J 7:99-101.

Kalivas PW, Nakamura M (1999) Neural systems for behavioral activation and reward. Curr Opin Neurobiol 9:223-227.

Kelley AE (1999) Neural integrative activities of nucleus accumbens subregions in relation to learning and motivation. Psychobiology 27:198-213.

Knable MB, Weinberger DR (1997) Dopamine, the prefrontal cortex and schizophrenia. J Psychopharmacol 11:123-131.

Koob GF, Le Moal M (1997) Drug abuse: hedonic homeostatic dysregulation. Science 278:52-58.

Kuczenski R, Segal DS (1989) Concomitant characterization of behavioral and striatal neurotransmitter responses to amphetamine using in vivo microdialysis. J Neurosci 9:2051-2065.

Malva JO, Carvalho AP, Carvalho CM (1994) Modulation of dopamine and noradrenaline release and of intracellular $\mathrm{Ca}^{2+}$ concentration by presynaptic glutamate receptors in hippocampus. $\mathrm{Br} \mathrm{J}$ Pharmacol 113:1439-1447.

Maycox PR, Hell JW, Jahn R (1990) Amino acid neurotransmission: spotlight on synaptic vesicles. Trends Neurosci 13:83-87.

Nicola SM, Kombian SB, Malenka RC (1996) Psychostimulants depress excitatory synaptic transmission in the nucleus accumbens via presynaptic D1-like dopamine receptors. J Neurosci 16:1591-1604.

Nishi A, Fisone G, Snyder GL, Dulubova I, Aperia A, Nairn AC, Greengard P (1999) Regulation of $\mathrm{Na}^{+} / \mathrm{K}^{+}$-ATPase isoforms in rat neostriatum by dopamine and protein kinase C. J Neurochem 73:1492-1501.

Pierce RC, Kalivas PW (1997) A circuitry model of the expression of behavioral sensitization to amphetamine-like psychostimulants. Brain Res Rev 25:192-216.

Reid MS, Hsu K, Berger SP (1997) Cocaine and amphetamine preferentially stimulate glutamate release in the limbic system: studies on the involvement of dopamine. Synapse 27:95-105.

Robbins TW, Everitt BJ (1996) Neurobehavioural mechanisms of reward and motivation. Curr Opin Neurobiol 6:228-236.

Schiffmann SN, Lledo P-M, Vincent J-D (1995) Dopamine D1 receptor modulates the voltage-gated sodium current in rat striatal neurons through a protein kinase A. J Physiol (Lond) 483:95-107.

Schoffelmeer ANM, Rice KC, Jacobson AE, Van Gelderen JG, Hogenboom F, Heijna MH, Mulder AH (1988) $\mu$-, $\delta$ - and $\kappa$-opioid receptormediated inhibition of neurotransmitter release and adenylate cyclase activity in brain slices: studies with fentanyl isothiocyanate. Eur J Pharmacol 154:169-178. 
Schoffelmeer ANM, De Vries TJ, Vanderschuren LJMJ, Tjon GHK, Nestby P, Wardeh G, Mulder AH (1997) Intermittent morphine administration induces a long-lasting synergistic effect of corticosterone on dopamine D1 receptor functioning in rat striatal neurons. Synapse 25:381-388.

Sihra TS, Nichols DG (1987) 4-Aminobutyrate can be released exocytotically from guinea-pig cerebral cortical synaptosomes. J Neurochem 49:261-267.

Smith AD, Bolam JP (1990) The neural network of the basal ganglia as revealed by the study of synaptic connections of identified neurons. Trends Neurosci 13:259-265.

Snyder GL, Fienberg AA, Huganir RL, Greengard P (1998) A dopamine/D1 receptor/protein kinase A/dopamine- and cAMP-regulated phosphoprotein $\left(M_{\mathrm{r}} 32 \mathrm{kDa}\right) /$ protein phosphatase-1 pathway regulates dephosphorylation of the NMDA receptor. J Neurosci 18:10297-10303.

Surmeier DJ, Eberwine J, Wilson CJ, Stefani A, Kitai ST (1992) Dopamine receptor subtypes colocalize in acutely-isolated rat striatonigral neurons. Proc Natl Acad Sci USA 89:10178-10182.

Surmeier DJ, Bargas J, Memings Jr HC, Nairn AC, Greengard P (1995) Modulation of calcium currents by a $\mathrm{D}_{1}$ dopaminergic protein kinase/ phosphatase cascade in rat neostriatal neurons. Neuron 14:385-397.

Tian Y, Kapatos G, Granneman JG, Bannon MJ (1994) Dopamine and $\gamma$-aminobutyrate acid transporters: differential regulation by agents that promote phosphorylation. Neurosci Lett 173:143-146.

Van Vliet BJ, De Vries TJ, Wardeh G, Mulder AH, Schoffelmeer ANM (1991) $\mu$-Opioid receptor-regulated adenylate cyclase activity in primary cultures of rat striatal neurons upon chronic morphine exposure. Eur J Pharmacol Mol Pharmacol 208:105-111.

Wang JKT, Andrews H, Thukral V (1992) Presynaptic glutamate receptors regulate noradrenaline release from isolated nerve terminals. J Neurochem 58:204-211.

Weiss S (1988) Excitatory amino acid-evoked release of ã-[ $\left[{ }^{3} \mathrm{H}\right]$ aminobutyric acid from striatal neurons in primary culture. J Neurochem 51:435-441.

White FJ, Hu X-T, Henri DJ (1993) Electrophysiological effects of cocaine in the rat nucleus accumbens: microiontophoretic studies. J Pharmacol Exp Ther 66:1075-1084.

Xue C-J, Ng JP, Li Y, Wolf ME (1996) Acute and repeated systemic amphetamine administration: effects on extracellular glutamate, aspartate, and serine levels in rat ventral tegmental area and nucleus accumbens. J Neurochem 67:352-363.

Zhang X-F, Hu X-T, White FJ (1998) Whole-cell plasticity in cocaine withdrawal: reduced sodium currents in nucleus accumbens neurons. J Neurosci 18:488-498. 